\title{
Start codon targeted (SCoT) polymorphism reveals genetic diversity of Manilkara in Thailand
}

\author{
ONGKARN VANIJAJIVA \\ Faculty of Science and Technology, Phranakhon Rajabhat University. Bangkok, 10220, Thailand. \\ Tel./fax.: 66-271-663375, `email: vanijajiva@gmail.com
}

Manuscript received: 29 December 2019. Revision accepted: 20 January 2020.

\begin{abstract}
Vanijajiva O. 2020. Start codon targeted (SCoT) polymorphism reveals genetic diversity of Manilkara in Thailand. Biodiversitas 21: 666-673. Manilkara consists of four species, namely, Manilkara hexandra, M. kauki, M. littoralis, and M. zapota in Thailand. Particularly, M. zapota (sapodilla), commonly known as Lamut in Thailand, is one of commercially notable edible fruits continues to be a highly valued tree and the fruits are a source of food and income. The objective of this research was to determine the diversity and relationship of Manilkara accessions derived from districts in Thailand based on DNA profiles. Genetic diversity and relationship of all accessions were investigated using Start Codon Targeted (SCoT) marker analysis. Of 30 SCoT primers screened, 27 SCoT primers were identified to be polymorphism. A total of 176 DNA bands with size varied from $120 \mathrm{bp}$ to $1200 \mathrm{bp}$ were amplified, and $101(57.38 \%)$ of them were polymorphic. Based on similarity coefficients, total of 36 accessions were clustered into two groups. The cluster of polymorphism generated by SCoT was associated with their locality and morphological characters. Therefore, the present data provide high-valued information for the management of germplasm, genetic improvement, and conservation of the genetic resources of Manilkara accessions.
\end{abstract}

Keywords: Genetic diversity, Manilkara, Sapodilla, SCoT, Thailand

\section{INTRODUCTION}

Manilkara is a genus of trees in the Sapotaceae, consisting of 80 species distributed throughout the tropics about 30 in South and Central America, 35 in Africa and 14 in Southeast Asia. The genus even spread of species diversity across all major tropical regions of the globe makes Manilkara an ideal candidate for in-depth biodiversity observation (Armstrong 2010). In Thailand, about four species have been informed namely (Figure 1), Manilkarahexandra (Roxb.) Dubard M. kauki (L.) Dubard, M. littoralis (Kurz) Dubard and M. zapota (L.) P. Royen (Chantaranothai, 1999). Particularly, M. zapota, known as Sapodilla or Sapota, Chikoo, Naseberry, Nispero or Lamut is one of several Thai fruits that have received very little scientific attention (Bano and Ahmed 2017). In order to develop strategies for Manilkara improvement and to preserve unique Manilkara germplasm, it is necessary to have an understanding of the genetic diversity particular within $M$. zapota, an economically important species of genus Manilkara (Armstrong 2013; Thompson et al. 2015), continues to be a highly valued tree and the fruits are a source of food and income for Thailand (Kunyamee et al. 2010; Sunpapao et al. 2017; Madani et al. 2018).

Molecular markers have been used very frequently in ecological, taxonomical, diversity, conservation, phylogenic and genetic studies amongst organisms (Avise 1994; Weising et al. 2005; Sheth and Thaker 2017; Srivastava et al. 2020). After the advent of Polymerase chain reaction (PCR) several advancements and introduction of new concepts were employed in the improvement of various types of molecular marker technologies like amplified fragment length polymorphism (AFLP) (Vos et al. 1995; Roncallo et al. 2019), inter simple sequence repeats (ISSRs), (Vanijajiva 2012; Husnudin et al. 2019), random amplified polymorphic DNA (RAPD) (Vanijajiva et al. 2005; Ihwan and Hakim 2019), Simple Sequence Repeats (SSR (Dewi et al. 2020), Single Sequence Polymorphism (SNP) (Trick et al. 2009; Luo et al. 2010; Bayerl et al. 2018). For distinct genetic applications amongst diverse plant species, different markers have been used by various researchers in commercial fruit accessions. An innovative molecular marker known as Start Codon Targeted (SCoT) polymorphism targets on short ATG start codon in plant genes has been reported (Collard and Mackill 2009; Satya et al. 2016; Jedrzejczyk 2020). It has several advantages over RAPD, ISSR, and AFLP, as it is more consistent, produce more reproducible and reliable bands and can be used effectively for population studies, genetic mapping in different plants and in the marker-assisted selection programs (Gorji et al. 2011; Xiong et al. 2011; Alikhani et al. 2014; Gajera et al. 2014; Yue et al. 2019). Similar to RAPD and ISSR markers, SCoT are important markers that could be used for different genetic application such as, to assess genetic diversity and structure, in bulk segregation analyses, quantitative trait loci (QTL) mapping and DNA fingerprinting (Luo et al. 2012; Gao et al. 2014; Emami et al. 2018; Gupta et al. 2019). These markers are directly involved in relation to gene function and can be utilized in genotyping and to explore polymorphism. SCoT markers have been successfully practiced for diversity analysis and diagnostic fingerprinting in many agricultural species 
(Gorji et al. 2011; Xiong et al. 2011; Agarwal et al. 2019; Saboori et al. 2020). Therefore, this reports the use of an innovative molecular marker technology SCoT to assess the levels of genetic variation in 36 Manilkara accessions collected from Thailand. The objective of this study is preliminary to evaluate biodiversity of genus Manilkara in Thailand by SCoT marker.

\section{MATERIALS AND METHODS}

\section{Plant materials}

A set of 36 accessions of Manilkara were collected and selected as five plants per cultivar in Thailand (Table 1). Identification of plants into species was done by observing morphological characteristics, checking references and comparing with herbarium specimens at several herbaria. Then, the names were verified to the correct botanical names by way of taxonomic study (Chantaranothai, 1999). Thirty-three M. zapota (MZ) were sampled. In addition, a representative of Manilkara, M. littoralis (ML), M. kauki $(\mathrm{MK})$ and $M$. hexandra $(\mathrm{MH})$, were included as outgroup references. All species are widely cultivated in Thailand, in particular, $M$. zapota is a commonly cultivated fruit species. The obtained fresh leaves were stored at $-20{ }^{\circ} \mathrm{C}$ until further processing.

\section{DNA extraction}

Genomic DNA was extracted from the leaves of 36 Manilkara accessions using the CTAB method with minor modification (Doyle and Doyle 1987; Doyle and Doyle 1990). The leaves $(500 \mathrm{mg})$ were ground in a mortar with a pestle. Extraction buffer [ (1\% (w/v) CTAB, $50 \mathrm{mM}$ Tris$\mathrm{HCl}(\mathrm{pH} 8), 0.7 \mathrm{M} \mathrm{NaCl}, 0.1 \%$ ß-mercaptoethanol)] $500 \mu \mathrm{l}$ was added and the solution was incubated at $60 \mathrm{Co}$ for 30 min. The homogenate was mixed with 25: 24: 1 phenol: chloroform: isoamyl alcohol $(\mathrm{v} / \mathrm{v} / \mathrm{v})$ by gentle inversion. After centrifugation at $13,000 \mathrm{rpm}$ for $15 \mathrm{~min}$, the upper aqueous layer was transferred to a new tube. RNA was removed by treating with $2.5 \mu \mathrm{l}$ of the RNase $(10 \mu \mathrm{g} / \mu \mathrm{l})$ for $30 \mathrm{~min}$ at $37^{\circ} \mathrm{C}$. The extraction of DNA with phenol/chloroform/isoamyl alcohol was repeated one more time. DNA in the solution was precipitated with 0.6 volumes of ice-cold isopropanol and washed with $70 \%$ ethanol. Following this, the DNA was extracted using CTAB DNA extraction protocol without RNase. The process was repeated until the DNA pellet was free of color (two to three times) and the final pellet was dissolved in sterile deionized water (Vanijajiva 2014; Kaewpongumpai et al. 2016). DNA quality was using Nanodrop Spectrophotometer (Thermo scientific Nanodrop 1000, USA) at the absorbance ratio of 260 and $280 \mathrm{~nm}$ providing a value of 1.7-1.8 which determines pure DNA preparation. Quality of DNA fragment was electrophoretically analyzed through $0.8 \%$ agarose gel using $1 \mathrm{X}$ TAE buffer (Gao et al. 2014). A 500 base pair ladder (purchased from Chromos biotech) was loaded into the gel as molecular size marker. The gel was visualized by staining with ethidium bromide $(1 \mu \mathrm{L} / 10 \mathrm{~mL})$ and the bands were seen under UV light by using gel documentation system alpha imager hp (Innotech, USA). The DNA was stored at $-20{ }^{\circ} \mathrm{C}$, for further use as templates for PCR amplification.
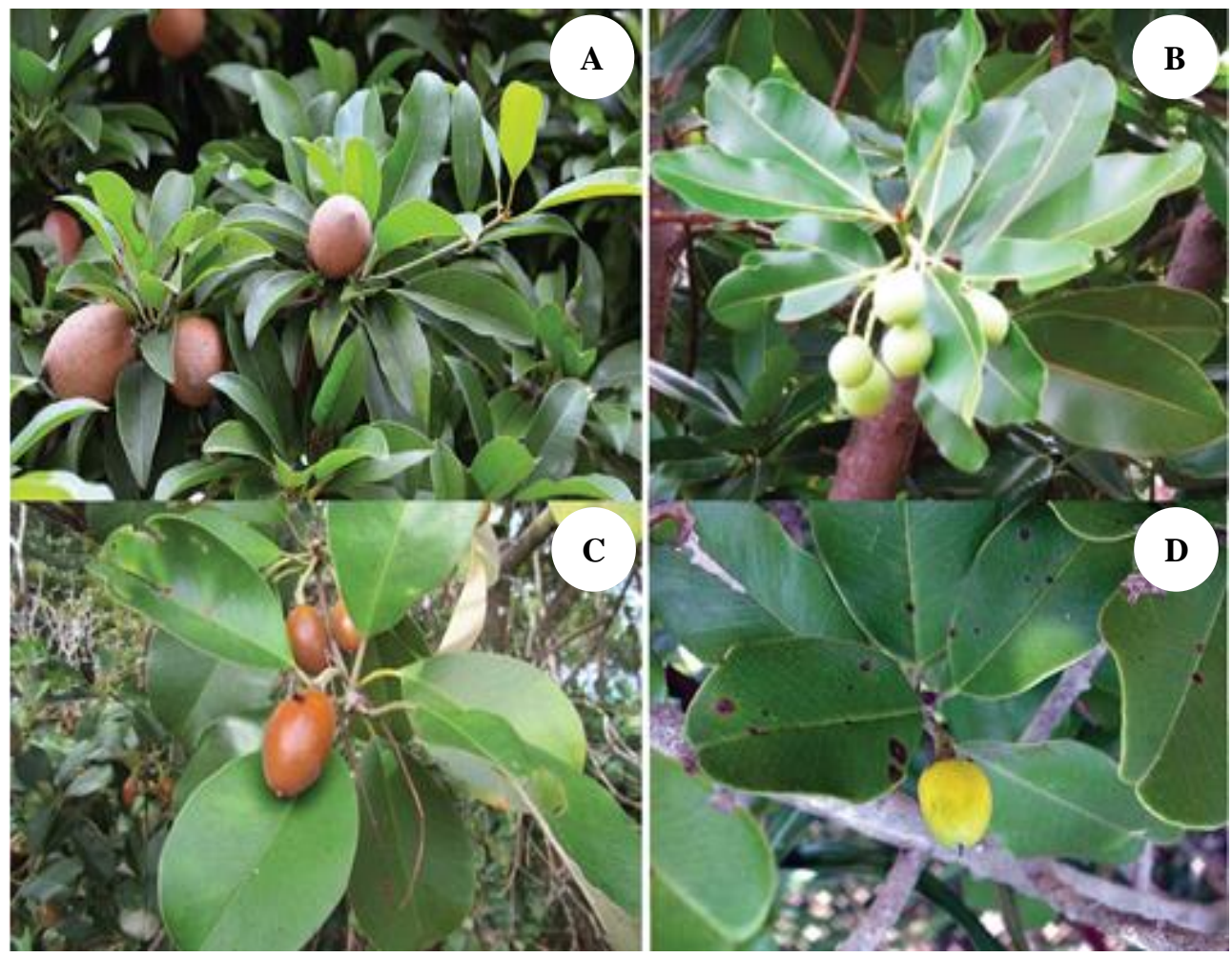

Figure 1. Manilkara in Thailand. A. M. zapota, B. M. littoralis C. M. kauki, D. M. hexandra 
Table 1. Sample of 36 accessions of Manilkara used in this study with the code number, province, coordinates, and vernacular name

\begin{tabular}{|c|c|c|c|c|}
\hline \multirow{2}{*}{ Code } & \multirow{2}{*}{ Province } & \multicolumn{2}{|c|}{ Sample site } & \multirow{2}{*}{ Vernacular } \\
\hline & & Longitude (E) & Latitude (N) & \\
\hline MZ01 & Sukhothai & $99^{\circ} 50^{\prime} 46^{\prime \prime}$ & $17^{\circ} 13^{\prime} 07^{\prime \prime}$ & Lamut Kai Hahn \\
\hline MZ02 & Chai Nat & $100^{\circ} 14^{\prime} 32^{\prime \prime}$ & $15^{\circ} 20^{\prime} 01^{\prime \prime}$ & Lamut Sida \\
\hline MZ03 & Songkhla & $100^{\circ} 54^{\prime} 82^{\prime \prime}$ & $7^{\circ} 16^{\prime} 24^{\prime \prime}$ & Lamut Kai Hahn \\
\hline MZ04 & Phetchabun & $101^{\circ} 73^{\prime} 74^{\prime \prime}$ & $16^{\circ} 73^{\prime} 74^{\prime \prime}$ & Lamut Kai Hahn \\
\hline MZ05 & Nakhon Nayok & $101^{\circ} 20^{\prime} 90^{\prime \prime}$ & $14^{\circ} 19^{\prime} 81^{\prime \prime}$ & Lamut Krasuey \\
\hline MZ06 & Nong Bua Lamphu & $102^{\circ} 33^{\prime} 54^{\prime \prime}$ & $16^{\circ} 88^{\prime} 67^{\prime \prime}$ & Lamut Markok \\
\hline MZ07 & Ratchaburi & $100^{\circ} 00^{\prime} 33^{\prime \prime}$ & $13^{\circ} 55^{\prime} 87^{\prime \prime}$ & Lamut Kai Hahn \\
\hline MZ08 & Phatthalung & $100^{\circ} 06^{\prime} 59^{\prime \prime}$ & $7^{\circ} 60^{\prime} 89^{\prime \prime}$ & Lamut Kai Hahn \\
\hline MZ09 & Sa Kaeo & $102^{\circ} 08^{\prime} 46^{\prime \prime}$ & $13^{\circ} 81^{\prime} 25^{\prime \prime}$ & Lamut Krasuey \\
\hline MZ10 & Bangkok & $100^{\circ} 62^{\prime} 65^{\prime \prime}$ & $13^{\circ} 87^{\prime} 97^{\prime \prime}$ & Lamut Kai Hahn \\
\hline MZ11 & Kamphaeng Phet & $99^{\circ} 51^{\prime} 58^{\prime \prime}$ & $16^{\circ} 38^{\prime} 61^{\prime \prime}$ & Lamut Kai Hahn \\
\hline MZ12 & Phra Nakhon Si Ayutthaya & $100^{\circ} 60^{\prime} 39^{\prime \prime}$ & $14^{\circ} 44^{\prime} 10^{\prime \prime}$ & Lamut Sida \\
\hline MZ13 & Phitsanulok & $100^{\circ} 59^{\prime} 26^{\prime \prime}$ & $16^{\circ} 76^{\prime} 09^{\prime \prime}$ & Lamut Kai Hahn \\
\hline MZ14 & Nakhon Sawan & $100^{\circ} 35^{\prime} 56^{\prime \prime}$ & $15^{\circ} 26^{\prime} 00^{\prime \prime}$ & Lamut Kai Hahn \\
\hline MZ15 & Prachinburi & $101^{\circ} 39^{\prime} 98^{\prime \prime}$ & $14^{\circ} 18^{\prime} 37^{\prime \prime}$ & Lamut Krasuey \\
\hline MZ16 & Pathum Thani & $100^{\circ} 57^{\prime} 01^{\prime \prime}$ & $14^{\circ} 02^{\prime} 71^{\prime \prime}$ & Lamut Kai Hahn \\
\hline MZ17 & Nonthaburi & $100^{\circ} 36^{\prime} 44^{\prime \prime}$ & $13^{\circ} 83^{\prime} 04^{\prime \prime}$ & Lamut Kai Hahn \\
\hline MZ18 & Nong Khai & $102^{\circ} 74^{\prime} 42^{\prime \prime}$ & $17^{\circ} 84^{\prime} 91^{\prime \prime}$ & Lamut Markok \\
\hline MZ19 & Sakon Nakhon & $104^{\circ} 19^{\prime} 15^{\prime \prime}$ & $17^{\circ} 07^{\prime} 88^{\prime \prime}$ & Lamut Markok \\
\hline MZ20 & Suphan Buri & $100^{\circ} 72^{\prime} 73^{\prime \prime}$ & $14^{\circ} 73^{\prime} 72^{\prime \prime}$ & Lamut Kai Hahn \\
\hline MZ21 & Udon Thani & $102^{\circ} 87^{\prime} 17^{\prime \prime}$ & $17^{\circ} 39^{\prime} 62^{\prime \prime}$ & Lamut Markok \\
\hline MZ22 & Nakhon Pathom & $100^{\circ} 19^{\prime} 79^{\prime \prime}$ & $13^{\circ} 87^{\prime} 86^{\prime \prime}$ & Lamut Sida \\
\hline MZ23 & Sing Buri & $100^{\circ} 43^{\prime} 29^{\prime \prime}$ & $14^{\circ} 80^{\prime} 42^{\prime \prime}$ & Lamut Sida \\
\hline MZ24 & Ang Thong & $100^{\circ} 44^{\prime} 72^{\prime \prime}$ & $14^{\circ} 69^{\prime} 57^{\prime \prime}$ & Lamut Sida \\
\hline MZ25 & Loei & $101^{\circ} 95^{\prime} 36^{\prime \prime}$ & $17^{\circ} 29^{\prime} 18^{\prime \prime}$ & Lamut Markok \\
\hline MZ26 & Uttaradit & $100^{\circ} 03^{\prime} 05^{\prime \prime}$ & $17^{\circ} 67^{\prime} 18^{\prime \prime}$ & Lamut Kai Hahn \\
\hline MZ27 & Phichit & $100^{\circ} 30^{\prime} 71^{\prime \prime}$ & $16^{\circ} 34^{\prime} 46^{\prime \prime}$ & Lamut Kainan \\
\hline MZ28 & Uthai Thani & $99^{\circ} 91^{\prime} 27^{\prime \prime}$ & $15^{\circ} 58^{\prime} 28^{\prime \prime}$ & Lamut Sida \\
\hline MZ29 & Chonburi & $101^{\circ} 41^{\prime} 11^{\prime \prime}$ & $13^{\circ} 29^{\prime} 99^{\prime \prime}$ & Lamut Kai Hahn \\
\hline MZ30 & Kam Phaeng Phet & $99^{\circ} 69^{\prime} 53^{\prime \prime}$ & $16^{\circ} 28^{\prime} 78^{\prime \prime}$ & Lamut Kai Hahn \\
\hline MZ31 & Chachoengsao & $101^{\circ} 06^{\prime} 05^{\prime \prime}$ & $13^{\circ} 66^{\prime} 17^{\prime \prime}$ & Lamut Krasuey \\
\hline MZ32 & Trat & $102^{\circ} 54^{\prime} 56^{\prime \prime}$ & $12^{\circ} 18^{\prime} 35^{\prime \prime}$ & Lamut Kai Hahn \\
\hline MZ33 & Rayong & $101^{\circ} 34^{\prime} 92^{\prime \prime}$ & $12^{\circ} 67^{\prime} 99^{\prime \prime}$ & Lamut Kai Hahn \\
\hline ML & Surat Thani & $99^{\circ} 50^{\prime} 46^{\prime \prime}$ & $9^{\circ} 73^{\prime} 17^{\prime \prime}$ & Lamut pa \\
\hline MK & Nonthaburi & $100^{\circ} 43^{\prime} 91^{\prime \prime}$ & $13^{\circ} 83^{\prime} 35^{\prime \prime}$ & Lamut Thai \\
\hline MH & Kanchanaburi & $99^{\circ} 44^{\prime} 80^{\prime \prime}$ & $14^{\circ} 00^{\prime} 14^{\prime \prime}$ & Ket \\
\hline
\end{tabular}

\section{SCoT-PCR amplification}

Thirty SCoT primers described by Collard and Mackill (Collard and Mackill 2009) were initially screened for analysis (Table 2). PCR was performed using a Thermohybaid Px2 (Roche Molecular Systems, Inc., USA). PCR was optimized for testing the SCoT method. The final optimized protocol is reported here. All PCR reactions were performed within a total volume of $10 \mu \mathrm{L}$ in 96-well plates using a PTC-100 Thermocycler (MJ Research Model PTC100). PCR reaction mixtures contained PCR buffer (Promega; $20 \mathrm{mM}$ Tris- $\mathrm{HCl}$ (pH 8.4), $50 \mathrm{mM} \mathrm{KCl}$ ), $5 \mathrm{mM}$ $\mathrm{MgCl}_{2}, \quad 0.24 \mathrm{mM}$ of each deoxyribonucleotide triphosphates, $0.5 \mathrm{U}$ of Taq polymerase (Promega), and 0.8 $\mu \mathrm{m}$ of primer. Each reaction contained $25 \mathrm{ng}$ of template DNA. A standard PCR cycle was used: an initial denaturation step at $94^{\circ} \mathrm{C}$ for $3 \mathrm{~min}$, followed by 35 cycles of $94^{\circ} \mathrm{C}$ for $1 \mathrm{~min}, 50^{\circ} \mathrm{C}$ for $1 \mathrm{~min}$, and $72^{\circ} \mathrm{C}$ for $2 \mathrm{~min}$; the final extension at $72^{\circ} \mathrm{C}$ was held for 5 min (Collard and Mackill 2009; Luo et al. 2010). After amplification, PCR products were electrophoretically analyzed through $1.5 \%$ agarose gels, in 1X TBE buffer in a Protean II xi Cell (Bio-
Rad, USA). Gels were stained with ethidium bromide and photographed under UV light by using gel documentation system alpha imager hp (Innotech, USA).

\section{Bands profile and analysis}

The SCoT products were all analyzed by agarose $(1.8 \%$ w/v) gel electrophoresis at $150 \mathrm{~A}$ for 30 minutes in $0.04 \mathrm{M}$ TAE (Tris-acetate $0.001 \mathrm{M}$-EDTA) buffer $\mathrm{pH} 8$. The gels were stained with ethidium bromide $(10 \mathrm{mg} / \mathrm{mL})$. The gels were viewed and photographed by Bio-Imaging System (Syngene, Genegenuis). To determine SCoT profiles, the size of each DNA band was inferred by comparison with a 100 bp DNA ladder (Promega), used as a molecular weight marker (M). Polymorphisms at all loci were confirmed by three repeating tests for each primer at different times.

Only strong and reproducible SCoT bands were scored. Different patterns observed were scored as discrete variables, using 1 to indicate the presence and 0 to indicate the absence of a unique pattern using the software PAST 3.0 for Windows (Hammer 2013) for the statistical analyses. Relationships among individuals were determined 
by the distance matrix method. Nei and Li's Dice similarity coefficients were calculated for all pair-wise comparisons between individual samples to provide a distance matrix (Nei and Li, 1979). A dendrogram was constructed from this matrix on the basis of the hierarchical cluster analysis, which is based on the average linkage between group, i.e. the unweighed pair-group method algorithm (UPGMA) as described by Sneath and Sokal (1973). A principal coordinate analysis (PCoA) was also conducted using a genetic similarity matrix obtained from the binary data set.

\section{RESULTS AND DISCUSSION}

The extraction of high-quality DNA from Manilkara is challenging because of presence of high polyphenolics in the tissues. A high throughput DNA extraction protocol is requirement. The presence of polyphenols, which are influential oxidizing agents show in many tropical plant species, can decrease the yield and purity by binding covalently with the extracted DNA production it useless of most research applications (Doyle and Doyle 1990; Vanijajiva 2011). The extraction of high-quality DNA was optimized by re-extracting the DNA using CTAB DNA isolation protocol and phenol: chloroform: isoamyl alcohol extraction instead of chloroform: isoamyl alcohol extraction (Doyle and Doyle, 1987; Vanijajiva 2014). The polyphenolics with the DNA were simply removed and good SCoT electrophoretograms were obtained with all samples. DNA extracted from Manilkara leaf using an above modified gave a good and adequate quality DNA for PCR reaction. DNA isolated by minor modification method yielded strong and reliable amplification products and the amount of DNA extracted from the accessions ranged from 75 to $125 \mu \mathrm{g} / \mathrm{mg}$ fresh weight leaf material. The ratios of A260/A280 varied from 1.81 to 1.96 . The quality of DNA was also tested by PCR, which confirmed that the DNAs were suitable for PCR reaction (Ibrahim et al. 2019; Yue et al. 2019). The parameters for the SCoT protocol from Manilkara sample were also studied. Numerous parameters had an effect on banding patterns and reproducibility such as concentration of dNTPs, magnesium chloride concentration, concentration of enzyme, concentration of primer and concentration of template DNA, but the concentration of template DNA and magnesium chloride were most important. The result clearly showed that at 50 ng template DNA and $\mathrm{MgCl}_{2} 5 \mathrm{mM}$ concentration was suitable for further PCR analysis.

The present study is first reported to have shown significant genetic polymorphism amongst various Manilkara accessions using SCoT markers (Heaton et al. 1999; Meghala et al. 2005; Thompson et al. 2015; Martínez-Natarén et al. 2017; Sari et al. 2018). This examination, a set of 30 SCoT primers were preliminary verified in MZ01 sample from Sukhothai province to examine genetic polymorphisms, out of total, 30 SCoT primers produced unambiguous and reproducible banding profile with 120-1200 bp product size but only three SCoT primers (SCoT12, SCoT20, SCoT29) failed to amplify the Manilkara genomic DNA (Figure 2). A total of 176 scorable bands were identified through the amplification of 27 SCoT primers in 36 Manilkara taxa. The amplification ranged from three bands to 12 bands. Moreover, an average PCR amplification found to be $57.38 \%$ and polymorphic information content ranged from 33.33 to $100 \%$ polymorphisms (Table 2). Thus, the parameters such as primer polymorphism and polymorphic information content used in the present study are found to be supportive to examine markers for their usefulness in the fingerprinting process.

Furthermore, investigation of the genetic diversity and relationships in cultivar accessions is important for breeding, conservation, management, and application of the materials. Accurate identification of accessions in a germplasm collection is an important challenge faced in plant conservation and crop improvement projects (Gupta and Rustgi 2004; Agarwal et al. 2008; Madhumati 2014). Dissimilar from RAPD, AFLP, and ISSR marker system, SCoT is gene-targeted marker with multilocous nature and it can produce more evidence correlated with morphological traits and supportive in high genetic polymorphism (Xiong et al. 2011). In addition, Gorji et al. (2011) compared the polymorphism created using ISSR, RAPD and SCOT markers which also confirmed that SCoT method could distinguish all cultivars, and SCoT marker was more efficient and information. Particular for germplasm identification, molecular marker systems such as the SCoT can improve to the assessment of genetic diversity and relationships in plant relationships analysis as well as selective plant breeding because they are objective and offer reproducible means of identification, independent of environmental influences (Luo et al. 2010; Satya et al. 2016; Agarwal et al. 2019). In order to estimate genetic diversity among Manilkara accessions from Thailand, genetic similarity coefficients (GSC) were calculated. The similarity matrix obtained using Nei and Li's coefficient (Nei and Li, 1979). Similarity coefficients ranged from $0.15-1.00$ in 36 Manilkara accessions tested in the present experiment. Based on the matrix of similarity coefficient, the genetic relatedness of among 36 Manilkara accessions was constructed and shown in Figure 3. The analysis could group all 36 accessions studied into two clusters. Based on SCoT bands, genetic distances among the 36 accessions were calculated and a dendrogram was constructed by UPGMA method (Figure 3A). Associations among 36 Manilkara were also resolved by principal coordinate analysis (PCoA) (Figure 3B). In the diagram generated by PCoA, two main groups were shown which revealed a similar cluster result as that in the dendrogram, clearly, I and II in PCoA plot are exactly the same as the ones in cluster I and II in the dendrogram. The result of this research indicated that the genetic distance is correlated with phenotypic characters. The SCoT results from this study confirm the validity of separation since Manilkara emerged as a separate species and variety group. This indicates the potential power of SCoT marker in distinguishing genetic diversity at both the species and genus levels (Xiong et al. 2010; Luo et al. 2012; Gao et al. 2014; Emami et al. 2018; Jedrzejczyk 2020). 
Table 2. Sequence of SCoT primers and polymorphic SCoT bands and polymorphism of Manilkara accessions

\begin{tabular}{|c|c|c|c|c|c|}
\hline Primer & Sequences (5'-3') & Total bands & Polymorphic bands & \% Polymorphism & Size (bp) \\
\hline SCoT1 & CAACAATGGCTACCACCA & 11 & 5 & 45.40 & $250-700$ \\
\hline SCoT2 & CAACAATGGCTACCACCC & 12 & 6 & 50.00 & $300-700$ \\
\hline SCoT3 & CAACA $\overline{\mathrm{ATG}} \mathrm{GCTACCACCG}$ & 5 & 3 & 60.00 & $310-600$ \\
\hline SCoT4 & CAACA $\overline{\mathrm{ATG}} \mathrm{CCTACCACCT}$ & 9 & 5 & 55.55 & $250-700$ \\
\hline SCoT5 & CAACAATGGCTACCACGA & 5 & 2 & 40.00 & $350-700$ \\
\hline SCoT6 & CAACAATGGCTACCACGC & 7 & 5 & 71.42 & $300-900$ \\
\hline SCoT7 & CAACAATGGCTACCACGG & 7 & 3 & 42.85 & $250-1000$ \\
\hline SCoT8 & CAACA $\overline{\mathrm{ATG}} \mathrm{CCTACCACGT}$ & 8 & 3 & 37.50 & $250-1000$ \\
\hline SCoT9 & CAACAATGGCTACCAGCA & 5 & 2 & 40.00 & $220-700$ \\
\hline SCoT10 & CAACA $\overline{\mathrm{ATG} G C T A C C A G C C}$ & 7 & 5 & 71.42 & $450-1200$ \\
\hline SCoT11 & AAGCAATGGCTACCACCA & 5 & 3 & 60.00 & $250-500$ \\
\hline SCoT12 & ACGACATGGCGACCAACG & - & - & - & - \\
\hline SCoT13 & ACGAC $\overline{A T G} G C G A C C A T C G$ & 8 & 4 & 50.00 & $210-720$ \\
\hline SCoT14 & ACGACATGGCGACCACGC & 6 & 4 & 66.66 & $120-780$ \\
\hline SCoT15 & ACGACATGGCGACCGCGA & 9 & 5 & 55.55 & $150-850$ \\
\hline SCoT16 & ACCATGGCTACCACCGAC & 5 & 4 & 80.00 & $200-500$ \\
\hline SCoT17 & ACCATGGCTACCACCGAG & 10 & 5 & 50.00 & $250-750$ \\
\hline SCoT18 & ACCATGGCTACCACCGCC & 5 & 5 & 100.00 & $300-600$ \\
\hline SCoT19 & ACCATGGCTACCACCGGC & 6 & 3 & 50.00 & $360-600$ \\
\hline SCoT20 & ACCATGGCTACCACCGCG & - & - & - & - \\
\hline SCoT21 & ACGACATGGCGACCCACA & 3 & 3 & 100.00 & $220-320$ \\
\hline SCoT22 & AACCATGGCTACCACCAC & 7 & 5 & 71.42 & $290-600$ \\
\hline SCoT23 & CACC $\overline{A T G G C T A C C A C C A G ~}$ & 6 & 3 & 50.00 & $250-480$ \\
\hline SCoT24 & CACCATGGCTACCACCAT & 7 & 4 & 57.14 & $250-500$ \\
\hline SCoT25 & ACCATGGCTACCACCGGG & 4 & 4 & 100.00 & $290-500$ \\
\hline SCoT26 & ACC $\overline{A T G G C T A C C A C C G T C ~}$ & 5 & 3 & 60.00 & $450-700$ \\
\hline SCoT27 & ACCATGGCTACCACCGTG & 3 & 1 & 33.33 & $320-650$ \\
\hline SCoT28 & CCATGGCTACCACCGCCA & 7 & 3 & 42.85 & $250-750$ \\
\hline SCoT29 & CCATGGCTACCACCGGCC & - & - & - & - \\
\hline \multirow[t]{2}{*}{ SCoT30 } & CC $\overline{\overline{A T G} G C T A C C A C C G G C G}$ & 4 & 3 & 75.00 & $350-650$ \\
\hline & Total & 176 & 101 & 57.38 & $120-1200$ \\
\hline
\end{tabular}

A dendrogram using UPGMA and PCoA analysis was constructed based on the corresponding genetic similarity coefficient among the tested 36 Manilkara accessions Cluster I was further subdivided into three sub-clusters, including different three outgroup species, $M$. hexandra (MH), M. kauki (MK) and M. littoralis (ML), were completely separated from the M. zapota (MZ) species. While all $33 \mathrm{M}$. zapota accessions were group in Cluster II. The dendrogram showed that the Cluster II was further subdivided into two sub-clusters. The first sub-cluster IIa is the largest, including twenty-four varieties. The first cluster comprises of oval to round fruit types of Markok, Kai Hahn cultivars. The second sub-cluster IIb includes nine verities comprises Kra Suey and Sida verities. Morphologically, the accessions Markok and Kai Hahn showed fruit shape resemblances from oval to round shape, whereas inclusion of Kra Suey and Sida considered as elliptically shaped fruits. These observations reveal that affinities and grouping of varieties depend on fruit characteristics. The result of M. zapota in cluster II showed that the genetic similarity is correlated with morphology (Rekha et al. 2011). Therefore, clustering patterns obtained with SCoT primer amplification among genomic DNA template of 36 Manilkara accessions are in accordance with their morphology such as fruit characteristics. This is similar to several previous studies by SCoT marker which the results were similarly a good agreement with morphological cluster analysis. For example, Gajera and colleagues reported that SCoT marker scheme was beneficial for indigenous mango cultivar identification based on their morphological characters and fruit traits (Gajera et al. 2014). Similar to Yang et al. (2015) successfully employed SCoT analysis to study polymorphism among date plum persimmon accessions. Their result showed that this population was divided into five major clusters based on phenotypic traits. Recently, Yue and colleagues investigated the molecular variation and structure of grape germplasm cultivars, and advanced breeding lines to determine whether their sufficient genetic diversity still existed within commonly used cultivars. Their SCoT results were generated from 36 SCoT primers. The polymorphic rate was $100 \%$ among the 51 grape germplasm resources, reflecting a high degree of genetic diversity in the samples they examined and indicated that SCoT technique is in accordance with their fruit characteristics (Yue et al. 2019). In addition, Zeng et al. (2014) also considered SCoT is molecular marker genes, which could provide more evidence for breeding programs. This may be due to SCoT detects polymorphisms in coding sequences, because the primers were designed to amplify from the short conserved region surrounding the ATG translation start codon (Collard and Mackill 2009; Gorji et al. 2011). Therefore, amplification products generated from the SCoT marker technique may be associated with functional genes and their corresponding traits (Xiong et al. 2009; Gajera et al. 2014; Agarwal et al. 2019; Gupta et al. 2019). 


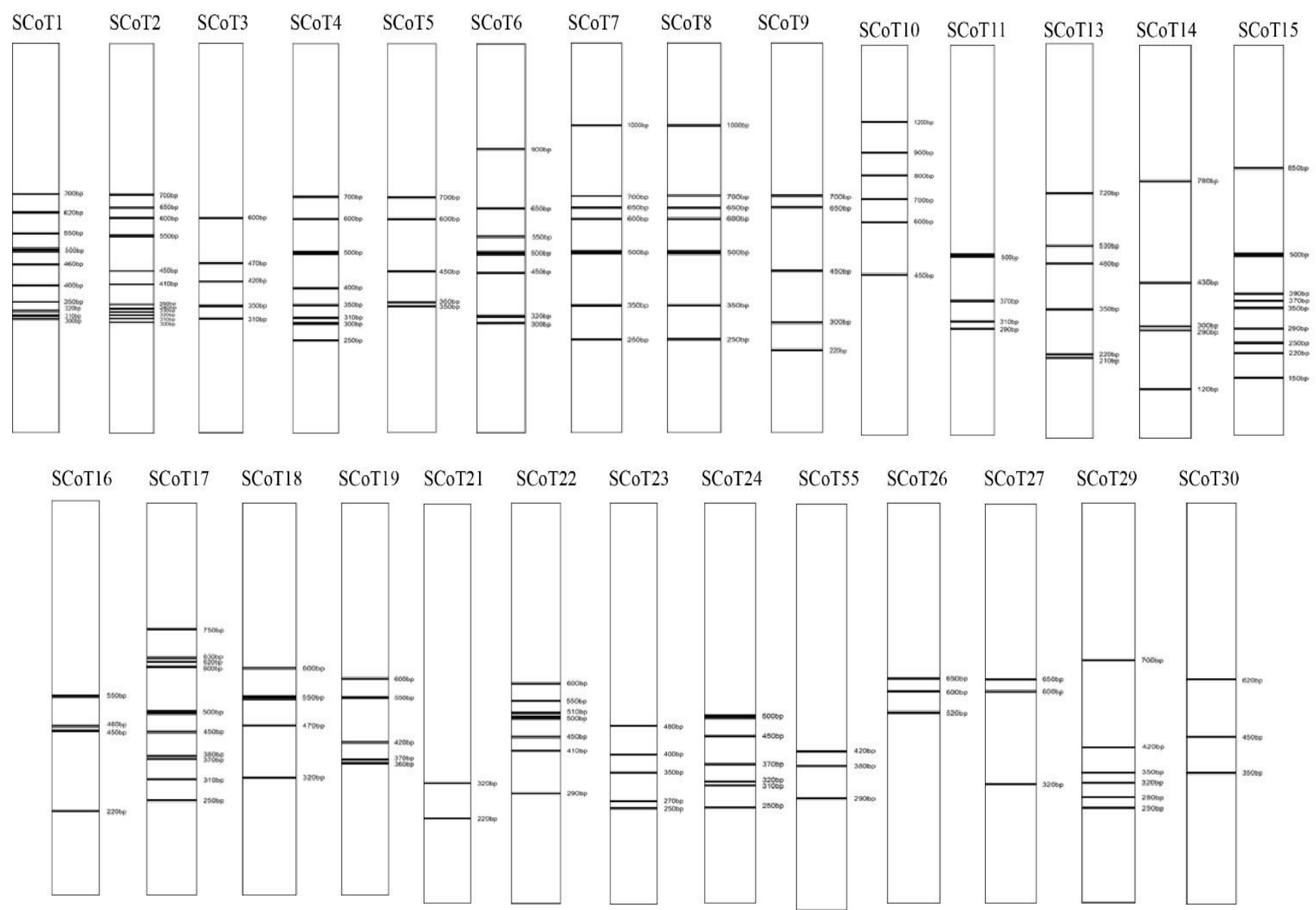

Figure 2. The representative SCoT profiles in this study. The electrophoretograms are employed as representative of clear, distinguished, stable profiles from 27 primers of sample from Sukhothai province to examine genetic polymorphisms.

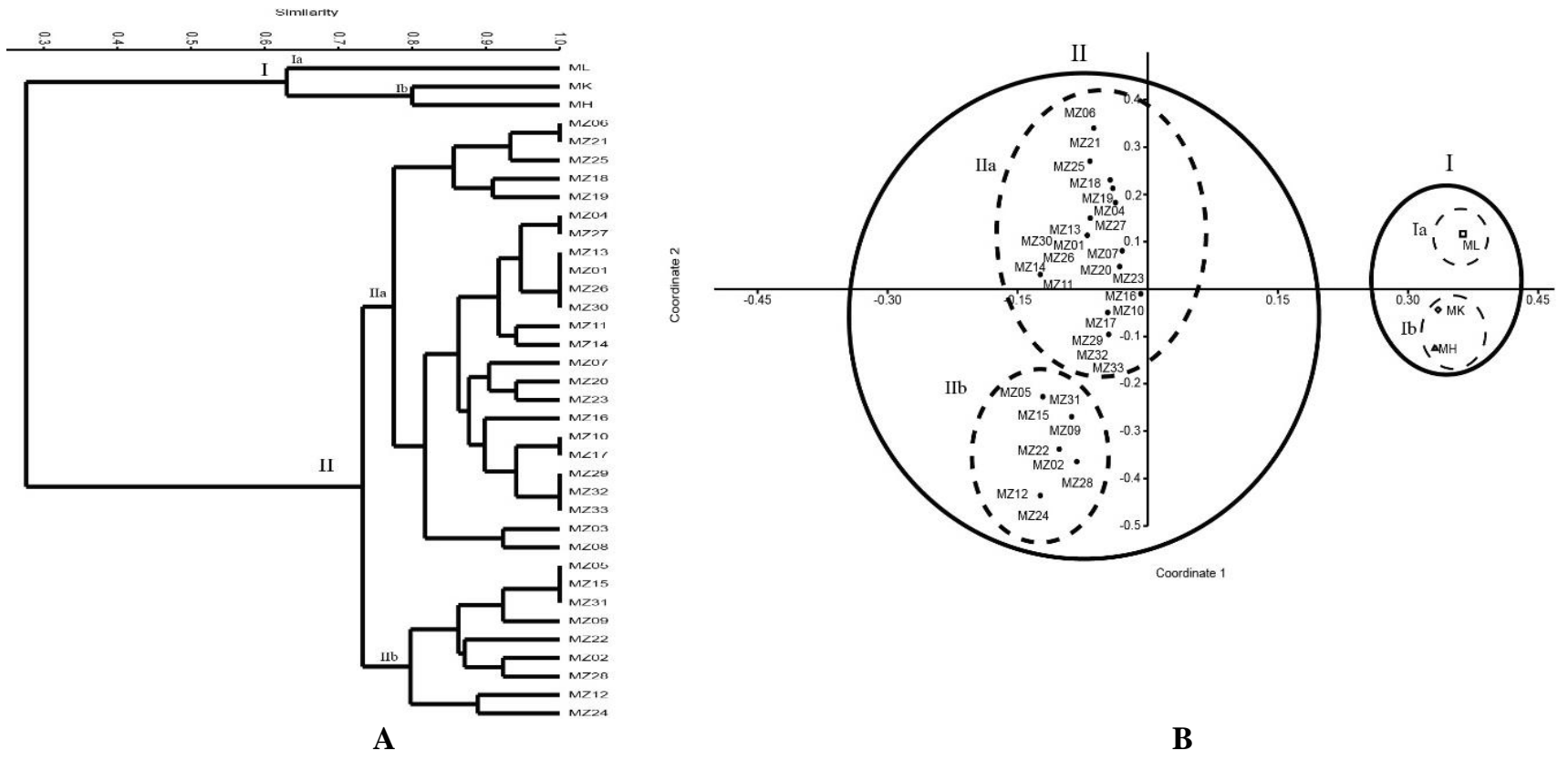

Figure 3. Relationship of 36 Manilkara accessions with SCoT analysis. A. Dendrogram analysis B. Principle coordinate analysis. Accession codes correspond to samples listed in Table 1. 
Future studies on this plant should include reciprocal transplants of Thai individuals, as well as common gardens of plants grown from seed. These additional experiments would give direct evidence of a presence or low of a genetic correlate to the observed morphological variation between these populations. In addition, germplasm collections need to be made of the different forms of $M$. zapota of the different cultivated varieties. A controlled breeding program would be very beneficial for stabilizing traits of interest and developing new varieties of M. zapota. Finally, agricultural studies should be directed with the different morphological types in Thailand to determine the viability of $M$. zapota as a crop plant.

In conclusion, the results provided bases for better Manilkara organization, core collection establishment, and exploration of diversity in breeding. This study, however, has not aimed here to specify which accessions, in particular, should be assigned to a core collection; this task awaits inclusion of morphological and digital image analyses of phenotypic traits as well as agronomic data. The work presented a possible method for applying the SCoT technique on Manilkara accession. This research found that the optimal primer sets obtained should facilitate the next SCoT analysis assays and be useful in the markerassisted breeding schemes of Manilkara in Thailand.

\section{ACKNOWLEDGEMENTS}

This work was supported by Phranakhon Rajabhat University and National Research Councils of Thailand. The author is gratefully acknowledged for all participates for supplying the plant materials and two anonymous reviewers for helpful comments on an earlier version of the manuscript. I wish to thank Nakanate Ngampak for his generous assistance during fieldwork in Thailand.

\section{REFERENCES}

Agarwal M, Shrivastava N, Padh H. 2008. Advances in molecular marker techniques and their applications in plant sciences. Plant Cell Rep 27: 617-631.

Agarwal A, Gupta V, Haq SU, Jatav PK, Kothari SL, Kachhwaha S. 2019. Assessment of genetic diversity in 29 rose germplasms using SCoT marker. JKSUES 31 (4): 780-788. DOI: 10.1016/j.jksus.2018.04.022

Alikhani L, Rahmani MS, Shabanian N, Badakhshan H., Khadivi-Khub A. 2014. Genetic variability and structure of Quercus brantii assessed by ISSR, IRAP and SCoT markers. Gene 552 (1): 176-183. DOI: 10.1016/j.gene.2014.09.034

Armstrong K. 2010 Systematics and biogeography of the pantropical genus Manilkara Adans. (Sapotaceae). [Dissertation]. Royal Botanic Garden and University of Edinburgh, Edinburgh. [Scotland]

Armstrong KE. 2013. A revision of the Asian-Pacific species of Manilkara (Sapotaceae). Edinburgh J Bot 70 (1): 7-56. DOI: 10.1017/S0960428612000327

Avise JC. 1994. Molecular Markers, Natural History and Evolution. Chapman and Hall, New York.

Bano M, Ahmed B. 2017. Manilkara zapota (L.) P. Royen (Sapodilla): A Review. IJARIIT 3 (6): 1364-1371.

Bayerl H, Kraus RH, Nowak C, Foerster DW, Fickel J, Kuehn, R. 2018. Fast and cost-effective single nucleotide polymorphism (SNP) detection in the absence of a reference genome using semi-deep next generation Random Amplicon Sequencing (RAM seq). Mol Ecol Resour 18 (1): 107-117. DOI: 10.1111/1755-0998.12717

Chantaranothai P. 1999. The Sapotaceae of Thailand. Thai Forest Bull Bot 27: 139-166.

Collard BC, Mackill DJ. 2009. Start codon targeted (SCoT) polymorphism: a simple, novel DNA marker technique for generating gene-targeted markers in plants. Pl Mol Biol Rep 27 (1): 86.

Dewi N, Nugroho K, Teryana RT, Lestari P. 2020. Evaluation of SSR and important agronomical characters of promising mutant lines of soybean. Biodiversitas 21 (1): 299-310. DOI: 10.13057/biodiv/d210137.

Doyle JJ, Doyle JL. 1987. A rapid DNA isolation procedure for small quantities of fresh leaf tissue. Phytochem Bull 19: 11-15.

Doyle JJ, Doyle JL 1990. Isolation of plant DNA from fresh tissue. Focus 12: $13-15$.

Emami A, Shabanian N, Rahmani MS, Khadivi A, Mohammad-Panah, N. 2018. Genetic characterization of the Crataegus genus: implications for in situ conservation. Sci Hort 231: 56-65. DOI: 10.1016/j.scienta.2017.12.014.

Gajera HP, Bambharolia RP, Domadiya RK, Patel SV, Golakiya BA. 2014. Molecular characterization and genetic variability studies associated with fruit quality of indigenous mango (Mangifera indica L.) cultivars. Pl Syst Evol 300 (5): 1011-1020.

Gao YH, Zhu YQ, Tong ZK, Xu ZY, Jiang XF, Huang CH. 2014. Analysis of genetic diversity and relationships among genus Lycoris based on start codon targeted (SCoT) marker. Biochem Syst Ecol 57: 221-226. DOI: 10.1016/j.bse.2014.08.002

Gorji AM, Poczai P, Polgar Z, Taller J. 2011. Efficiency of arbitrarily amplified dominant markers (SCoT, ISSR and RAPD) for diagnostic fingerprinting in tetraploid potato. Amer J Potato Res 88 (3): 226-237.

Gupta PK, Rustgi S. 2004. Molecular markers from the transcribed/expressed region of the genome in higher plants. Funct Integr Genom 4: 139-162.

Gupta V, Jatav PK, Haq SU, Verma KS, Kaul VK, Kothari SL, Kachhwaha S. 2019. Translation initiation codon (ATG) or SCoT markers-based polymorphism study within and across various Capsicum accessions: insight from their amplification, crosstransferability and genetic diversity. J Gen 98 (2): 61. DOI: 10.1007/s12041-019-1095-0

Hammer Ø. 2013. PAST: Paleontological statistics Version 3.0, Reference manual. Natural History Museum, University of Oslo, Norway.

Heaton HJ, Whitkus R, GómezPompa A. 1999. Extreme ecological and phenotypic differences in the tropical tree chicozapote (Manilkara zapota (L.) P. Royen) are not matched by genetic divergence: a random amplified polymorphic DNA (RAPD) analysis. Mol Ecol 8 (4): 627-632.

Husnudin U, Daryono B, Purnomo P. 2019. Genetic variability of Indonesian eggplant (Solanum melongena) based on ISSR markers. Biodiversitas 20 (10): 3049-3055. DOI: 10.13057/biodiv/d201038.

Ibrahim SD, Alsamman AM, Kahlifa K. 2019. A rapid method for DNA extraction of cotton mature fiber suitable for PCR fingerprinting. bioRxiv 529305. DOI: 10.1101/529305.

Ihwan I, Hakim L. 2019. Genetic diversity of Rhizophora mucronata in eastern region of Timor Island, Indonesia as revealed by RAPD. Biodiversitas 20 (11): 3364-3371. DOI: 10.13057/biodiv/d201133

Jedrzejczyk I. 2020. Genome size and SCoT markers as tools for identification and genetic diversity assessment in Echinacea genus. Indus Crops Products 144: 112055. DOI: 10.1016/j.indcrop.2019.112055

Kaewpongumpai S, Poeaim S, Vanijajiva O. 2016. Sequence-Related Amplified Polymorphism (SRAP) analysis for studying genetic characterization of Bouea macrophylla. Biodiversitas 17 (1): 539-543. DOI: 10.13057/biodiv/d170221

Kunyamee S, Ketsa S, Van Doorn WG. 2010. Gene expression of cellwall degrading enzymes in sapodilla (Manilkara zapota) fruit. ScienceAsia $36 \quad(1)$ : $18-25$. DOI: $10.2306 /$ scienceasia15131874.2010.36.018

Luo C, He XH, Chen H, Ou SJ, Gao MP. 2010. Analysis of diversity and relationships among mango cultivars using Start Codon Targeted (SCoT) markers. Biochem Syst Ecol 38 (6): 1176-1184. DOI: 10.1016/j.bse.2010.11.004.

Luo C, He XH, Chen H, Hu Y, Ou SJ. 2012. Genetic relationship and diversity of Mangifera indica L.: revealed through ScoT analysis. 
Genet Resour Crop Evol 59: 1505-1515. DOI: 10.1007/s10722-0119779-1

Madani B, Mirshekari A, Yahia E, Golding, JB. 2018. Sapota (Manilkara achras Forb.): Factors influencing fresh and processed fruit quality. Hort Reviews 45: 105-145.

Madhumati B. 2014. Potential and application of molecular markers techniques for plant genome analysis. Int J Pure App Biosci 2 (1): 169-188.

Martínez-Natarén DA, Parra-Tabla V, Munguía-Rosas MA. 2017. Genetic diversity and structure of the tree Manilkara zapota in a naturally fragmented tropical forest. J Trop Ecol 33 (4): 285-294.

Meghala R, Ravishankar KV, Lalitha A, Rekha A. 2005. Genetic diversity of Indian sapota (Manilkara zapota) cultivars characterized by RAPD markers. IPGRI PGR Newsletter 142: 43-46.

Nei M, Li WH. 1979. Mathematical model for studying genetic variation in terms of restriction endonucleases. PNAS 76 (10): 5269-5273.

Rekha A, Dinesh MR, Venugopalan R, Murthy BNS. 2011. Genetic correlation and cluster analysis in sapota (Manilkara zapota). J Hort Sci 6 (2): 101-104

Roncallo PF, Beaufort, V, Larsen AO, Dreisigacker S, Echenique V. 2019. Genetic diversity and linkage disequilibrium using SNP (KASP) and AFLP markers in a worldwide durum wheat (Triticum turgidum L. var durum) collection. PloS One 14 (6). DOI: 10.1371/journal.pone.0218562.

Saboori S, Noormohammadi Z, Sheidai M, Marashi S. 2020. SCoT molecular markers and genetic fingerprinting of date palm (Phoenix dactylifera L.) cultivars. Genet Resour Crop Evol 67 (1): 73-82. DOI 10.1007/s10722-019-00854-X.

Sari VK, Wulandari RA, Murti RH. 2018. Study on diversity of sapodilla (Manilkara zapota) by molecular marker in the Special Region of Yogyakarta. Agrivita 40 (2): 295-303. DOI: 10.17503/agrivita.v40i2.925

Satya P, Banerjee R, Karan M, Mukhopadhyay E, Chaudhary B, Bera A, Maruthi RT, Sarkar SK. 2016. Insight into genetic relation and diversity of cultivated and semi-domesticated under-utilized Crotalaria species gained using start codon targeted (SCoT) markers. Biochem Syst Ecol 66: 24-32. DOI: 10.1016/j.bse.2016.02.032

Sneath PHA, Sokal RR. 1973. Numerical Taxonomy. Freeman, San Francisco.

Sheth BP, Thaker VS. 2017. DNA barcoding and traditional taxonomy: an integrated approach for biodiversity conservation. Genome 60 (7): 618-628.

Srivastava A, Gupta S, Shanker K, Gupta N, Gupta AK, Lal RK. 2020. Genetic diversity in Indian poppy ( $P$. somniferum L. Srivastava) germplasm using multivariate and SCoT marker analyses. Indust Crops Products 144: 112050. DOI: 10.1016/j.indcrop.2019.112050.

Sunpapao A, Bunjongsiri P, Thithuan N, Arikit S. 2017. First report of Cephaleuros virescens causing algal leaf spot of Manilkara zapota in
Thailand. Plant Disease 101 (4): 636. DOI: 10.1094/PDIS-08-161111-PDN

Thompson KM, Culley TM, Zumberger AM, Lentz DL. 2015. Genetic variation and structure in the neotropical tree, Manilkara zapota (L) P. Royen (Sapotaceae) used by the ancient Maya. Tree Gen Genom 11 (3): 40. DOI: $10.1007 / \mathrm{s} 11295-015-0867-9$

Trick M, Long Y, Meng J, Bancroft I. 2009. Single nucleotide polymorphism (SNP) discovery in the polyploid Brassica napus using Solexa transcriptome sequencing. Plant Biotech J 7 (4): 334-346. DOI: $10.1111 / \mathrm{j} .1467-7652.2008 .00396 x$.

Vanijajiva O, Sirirugsa P, Suvachittanont W. 2005. Confirmation of relationships among Boesenbergia (Zingiberaceae) and related genera by RAPD. Biochem Syst Ecol 33 (2): 159-170.

Vanijajiva O. 2011. Genetic variability among durian (Durio zibethinus Murr.) cultivars in the Nonthaburi province, Thailand detected by RAPD analysis. J Agri Tech 7 (4): 1107-1116.

Vanijajiva O. 2012. The application of ISSR markers in genetic variance detection among Durian (Durio zibethinus Murr.) cultivars in the Nonthaburi province, Thailand. Proc Eng 32: 155-159.

Vanijajiva O. 2014. The biological diversity of Sinosenecio (Asteraceae: Senecioneae) in Thailand. J Agri Tech 10 (1): 147-157.

Vos P, Hogers R, Bleeker M, Reijans M, Lee TVD, Hornes M, Friters A, Pot J, Paleman J, Kuiper M, Zabeau M. 1995. AFLP: a new technique for DNA fingerprinting. Nucleic Acids Res 23 (21): 4407-4414.

Weising K, Nybom H, Pfenninger M, Wolff K, Kahl G. 2005. DNA fingerprinting in plants: principles, methods, and applications. CRC press. New York.

Xiong FQ, Tang RH, Chen ZL, Pan LH, Zhuang WJ. 2009. SCoT: a novel gene-targeted marker technique based on the translation start codon. Mol Plant Breed 7: 635-638.

Xiong F, Jiang J, Zhong R, Han Z, He L, Li Z, Zhuang W, Tang R. 2010. Application of SCoT molecular marker in genus Arachis. Acta Agro Sin 36 (12): 2055-2061.

Xiong F, Zhong R, Han Z, Jiang J, He L, Zhuang W, Tang R. 2011. Start codon targeted polymorphism for evaluation of functional genetic variation and relationships in cultivated peanut (Arachis hypogaea $\mathrm{L}$.) genotypes. Mol Rio Reports 38 (5): 3487-3494.

Yang Y, Yang T, Jing Z. 2015. Genetic diversity and taxonomic studies of date plum (Diospyros lotus L.) using morphological traits and SCoT markers. Biochem Syst Ecol 61: 253-259.

Yue Q, Zhang C, Wang Q, Wang W, Wang J, Wu Y. 2019. Analysis on genetic diversity of 51 Grape germplasm resources. Ciência Rural: 49 (11): e20190247. DOI: 10.1590/0103-8478cr20190247.

Zeng B, Zhang Y, Huang L, Jiang XM, Luo D, Yin G. 2014. Genetic diversity of orchardgrass (Dactylis glomerata L.) germplasms with resistance to rust diseases revealed by Start Codon Targeted (SCoT) markers. Biochem Syst Ecol 54: 96-102. DOI: 10.1016/j.bse.2013.12.028. 